Review

\title{
Environmental pollution affects molecular and biochemical responses during gonadal maturation of Astyanax fasciatus (Teleostei: Characiformes: Characidae)
}

\author{
Carlos E. Tolussi ${ }^{\mathrm{a}, *}$, Aline D. Olio Gomes ${ }^{\mathrm{a}}$, Anupama Kumar ${ }^{\mathrm{b}}$, Cristiele S. Ribeiro ${ }^{\mathrm{c}}$, \\ Fabiana L. Lo Nostro ${ }^{\mathrm{d}}$, Peter A. Bain ${ }^{\mathrm{b}}$, Gabriela B. de Souza ${ }^{\mathrm{e}}$, Rodrigo Da Cuña ${ }^{\mathrm{d}}$, Renato M. Honji ${ }^{\mathrm{a}}$, \\ Renata G. Moreira ${ }^{\mathrm{a}}$
}

\footnotetext{
${ }^{a}$ Laboratório de Metabolismo e Reprodução de Organismos Aquáticos, Departamento de Fisiologia, Instituto de Biociências, Universidade de São Paulo. Rua do Matão, Trav.14, $n^{\circ}$ 321, 05508-090 São Paulo, SP, Brazil

b Environmental Contaminant Mitigation and Technologies Program, CSIRO Land and Water, Private Bag No. 2, Glen Osmond SA 5064, Australia

${ }^{\mathrm{c}}$ Departamento de Biologia e Zootecnia, Universidade Estadual Paulista Júlio de Mesquita Filho, Campus de Ilha Solteira, Rua Monção, $n^{\circ} 226$, 15385-000 Ilha Solteira, Brazil

${ }^{\mathrm{d}}$ Laboratorio de Ecotoxicología Acuática, Departamento de Biodiversidad y Biología Experimental, Facultad de Ciencias Exactas y Naturales, Universidad de Buenos Aires \& IBBEA, CONICET-UBA, Ciudad Universitaria (C1428EHA), Buenos Aires, Argentina

e Centro de Aquicultura (CAUNESP). Universidade Estadual Paulista Júlio de Mesquita Filho, V. Acesso Prof. Paulo Donato Castelane s/n, 14884-900 Jaboticabal, SP, Brazil
}

\section{A R T I C L E I N F O}

\section{Keywords:}

Characidae

Anthropogenic impact

Endocrine disrupting compounds

Oocyte maturation

Estradiol

Vitellogenin

Gene expression

\begin{abstract}
A B S T R A C T
Endocrine disrupting compounds (EDCs) have the potential to alter fish reproduction at various levels of organization. The aim of this study was to assess the impact of a natural environment with heavily anthropogenic influence on the physiological processes involved in reproduction in the freshwater fish lambari (Astyanax fasciatus) using different biomarkers. Adult males and females were collected in different seasons from two distinct sites in the same watershed: Ponte Nova Reservoir (PN) considered a pristine or small anthropogenic influence reference point; and Billings Reservoir (Bil), subjected to a large anthropogenic impact. Biological indices, such as hepatosomatic index and gonadosomatic index (GSI), gonadal histomorphology, fecundity, and biomarkers such as plasma levels of estradiol (E2) as well as hepatic gene expression of its alfa nuclear receptor $(E R \alpha)$, were analyzed. Hepatic vitellogenin (VTG) gene expression was evaluated in both sexes, as an indicator of xenoestrogen exposure. Females collected at PN presented a typical annual variation reflected in GSI, whereas for those sampled at Bil the index did not change through the seasons. The higher concentration of E2 in males collected at Bil during spring/2013, together with the detection of VTG gene expression, suggest the presence of EDCs in the water. These EDCs may have also influenced fecundity of females from Bil, which was higher during winter and spring/2013. Gene expression of ER $\alpha$ and ovarian morphology did not differ between fish from both sites. Water conditions from Bil reservoir impacted by anthropic activity clearly interfered mainly with biomarkers of biological effect such as plasma E2 levels and absolute and relative fecundity, but also altered biomarkers of exposure as VTG gene expression. These facts support the notion that waterborne EDCs are capable of causing estrogenic activity in $A$. fasciatus.
\end{abstract}

\section{Introduction}

The introduction of contaminants into the environment due to anthropogenic activities may cause adverse effects on human health as well as wildlife populations (Vázquez et al., 2009). Among the contaminants affecting physiological processes of the aquatic biota are endocrine disrupting compounds (EDCs), which are defined as compounds which can interfere with the synthesis, secretion, transport, binding, action or elimination of naturally secreted hormones. A large number of EDCs present in natural environments originate from improper elimination from sewage in wastewater treatment plants (WWTPs) (Tan et al., 2007; Hassell et al., 2016). EDCs can act on

\footnotetext{
* Corresponding author.

E-mail address: ctolussi@usp.br (C.E. Tolussi).
} 
different pathways involving many physiological processes, such as reproduction, mimicking estrogen hormones (Vázquez et al., 2009), affecting sexual differentiation (Baroiller and Guiguen, 2001), gonadal development (Vested et al., 2014), and inducing vitellogenin synthesis in males (Moncaut et al., 2003; Vetillard and Bailhache, 2006). Several types of compounds are able to act as EDCs and affect reproductive processes in fish, including non-steroidal anti-inflammatory drugs (NSAIDs) (Fernandes et al., 2011; Ji et al., 2013) and metals (Driessnack et al., 2016), displaying estrogen-like activity and interference with estradiol receptors (Orn et al., 2006; Xu et al., 2008; Flick et al., 2014) and vitellogenin (VTG) synthesis (Scholz et al., 2004; Muncke and Eggen, 2006; Salierno and Kane, 2009). These studies have shown that different pollutants can deleteriously alter several physiological processes involved in reproduction at different organizational levels, potentially leading to population losses.

The presence of different EDCs in the aquatic environment has been well characterized in several studies around the world (Kinney et al., 2006; Kellar et al., 2014; Dias et al., 2015; Gorga et al., 2015; Minh et al., 2016). A wide range of water contaminants with EDC potential, such as NSAIDs (ibuprofen and diclofenac), that may bioaccumulate in organisms have been reported in Brazilian reservoirs, as is the case for the Billings reservoir (Bil) located in the metropolitan region of São Paulo, Brazil (Almeida and Weber, 2005). Bil reservoir is characterized by an intense anthropogenic activity, such as domestic sewage disposal and industrial effluents, deforestation and extensive land use (Mariani and Pompêo, 2008; Moschini-Carlos et al., 2010). Metals such as lead, chromium, mercury and zinc have also been detected in fish tissues since the 1980s at several points in this reservoir (Rocha et al., 1985), like the Taquacetuba and Bororé branches, where metal water concentrations are above those recommended by resolution of the Special Secretariat for the Environment. In fact, Oliveira (2012) detected high chromium concentrations in the liver of $60 \%$ of the sampled individuals of acará, Geophagus brasiliensis, 67\% of trahira, Hoplias malabaricus, $98 \%$ of lambari, Astyanax sp. and $100 \%$ of tilapia, Tilapia rendalli, which are in disagreement with the limit established by ANVISA Decree 55.871/65 (National Health Surveillance Agency). In addition, in the Taquecetuba branch, the concentration of metals (lead, copper, mercury, nickel and zinc) in the water has also been reported above those allowed by CONAMA Resolution 357 (Gomes et al., 2015).

Water and sediment monitoring studies led by the State Government of São Paulo demonstrated the presence of several contaminants and 21 out of 27 points analyzed were considered eutrophic (CETESB, 1996). In a later study, the Taquacetuba branch was considered super-eutrophic (Gomes et al., 2016), evidencing that Bil contains a large diversity of pollutants. Only a few fish species such as tilapia (Oreochromis niloticus), lambari (Astyanax sp.) and catfish (Rhamdia sp.) can be found in this water body as representative species (Castro et al., 2009). However, when the ecosystem is degraded, as is the case of Bil, it is difficult to understand whether the effects observed in organisms that inhabit in this area, are due to the action of contaminants or due to other stressors, like hypoxia or changes in the food chain (Hook et al., 2014). Then, in order to evaluate the effect of environmental pollution on those species, biomarkers of biological effects and exposure have to be used (Broerg et al., 2005; Hook et al., 2014). According to Hook et al. (2014), biomarkers of biological effects are indicators of physiological or biochemical changes as a consequence of exposure, such as condition indices or hormonal circulating levels; while biomarkers of exposure are defined as single or multiple pollutants with similar modes of action than can show an early response to contaminants and are typically specific to a class of contaminants, e.g., the induction of the vitellogenin in males induced by estrogenic compounds.

Astyanax fasciatus, commonly known as red-tailed lambari, is one of the species frequently found in Bil. reservoir. It is a small omnivorous fish considered an important prey for carnivorous species (Vilella et al., 2002; Gurgel, 2004). This species presents different reproductive strategies, which may vary according to the environmental conditions, presenting both asynchronous or synchronous oocyte development (Silva et al., 2010). Its distribution is very wide, reaching all of Central and South America, being found in both clean and polluted areas. All these features contributed to choose A. fasciatus as a sentinel species for environmental and toxicological test studies (Schulz and MartinsJúnior, 2001; Alberto et al., 2005; Carrasco-Letelier et al., 2006; Prado et al., 2011). Therefore, the aim of this study was to assess the impact of a heavily anthropogenic impacted environment on the physiological processes involved in reproduction in the freshwater fish lambari (Astyanax fasciatus) using different biomarkers at different organizational levels.

\section{Material and methods}

\subsection{Study area}

The study area comprised two important reservoirs of the Tietê River Basin, located in the Metropolitan Region of São Paulo (MRSP) in the State of São Paulo, Southeastern Brazil (see map at Gomes et al., 2015). Ponte Nova reservoir (PN), located at the Upper Reaches of the Tietê River Basin, is part of an environmental protected area occupied by rainforests, preserved ciliary forests and flood plains along the water course. Based on these characteristics, the PN reservoir was considered in this study as a reference site with minimal anthropogenic impact. Samples were collected in the Rio Claro branch (PN, 23 $34^{\prime} 36.5^{\prime \prime} \mathrm{S}$, $45^{\circ} 54^{\prime} 23.9^{\prime \prime} \mathrm{W}$ ), considered in a previous study as mesotrophic according to its trophic state index (TSI) (Table 1).

Bilings reservoir (Bil), located inside the MRSP, is a heavily impacted area due to its used for generation of electric power and as a public water supply. This reservoir is considered the second largest water reservoir of the MRSP, with a drainage area of $1560 \mathrm{~km}^{2}$ and a water surface of $106.6 \mathrm{~km}^{2}$ (Marceniuk and Hilsdorf, 2010). The Bil reservoir has seven branches with spatially differentiated biotic and pollutant characteristics, such as domestic sewage and industrial

Table 1

Hydrogeomorphical, physical, chemical, and biological characterization of the Ponte Nova (PN) and Billings (Bil) reservoirs.

\begin{tabular}{|c|c|c|}
\hline Variables & PN & Bil \\
\hline Surface area $\left(\mathrm{km}^{2}\right)$ & 25.7 & 106.6 \\
\hline $\begin{array}{r}\text { Water retention } \\
\text { time (days) }\end{array}$ & 720 & 80 \\
\hline Elevation (m) & 840 & 745 \\
\hline Temperature $\left({ }^{\circ} \mathrm{C}\right)$ & $16-23$ & $17-25.5$ \\
\hline $\mathrm{pH}$ & 6.5 & $7.5-9.5$ \\
\hline $\begin{array}{l}\text { Chlorophyll-a ( } \mu \mathrm{g} \\
\left.\mathrm{L}^{-1}\right)\end{array}$ & $0.7-4.1$ & $33.3-867.0$ \\
\hline Nitrate $\left(\mu \mathrm{g} \mathrm{L}^{-1}\right)$ & $9.5-200$ & $288.9-1045.9$ \\
\hline Nitrite $\left(\mu \mathrm{g} \mathrm{L}^{-1}\right)$ & $2.0-9.0$ & $8.1-25.7$ \\
\hline $\begin{array}{c}\text { Total nitrogen }(\mu \mathrm{g} \\
\left.\mathrm{L}^{-1}\right)\end{array}$ & $500.00-900.0$ & $430.0-473.6$ \\
\hline $\begin{array}{l}\text { Total phosphorus } \\
\quad\left(\mu \mathrm{g} \mathrm{L}^{-1}\right)\end{array}$ & $8.0-20.0$ & $54.6-402.2$ \\
\hline TSI & Mesotrophic & Super-hypereutrophic \\
\hline Ibuprofen (ng L $\left.{ }^{-1}\right)$ & $\mathrm{NF}$ & $10.0-78.2$ \\
\hline Diclofenac $\left(\mathrm{ng} \mathrm{L}^{-1}\right.$ ) & $\mathrm{NF}$ & $8.1-394.5$ \\
\hline $\begin{array}{l}\text { Total cadmium } \\
(\mathrm{mg} / \mathrm{kg})\end{array}$ & $<0.005$ & 0.005 \\
\hline Total lead (mg/kg) & $<0.01$ & $0.01-0.06$ \\
\hline $\begin{array}{l}\text { Total copper (mg/ } \\
\text { kg) }\end{array}$ & $<0.005$ & $0.005-0.1$ \\
\hline $\begin{array}{l}\text { Total mercury (mg/ } \\
\text { kg) }\end{array}$ & $<0.0002$ & $0.0002-0.27$ \\
\hline $\begin{array}{l}\text { Total nickel (mg/ } \\
\quad \mathrm{kg} \text { ) }\end{array}$ & $<0.01$ & $0.01-0.11$ \\
\hline References & $\begin{array}{l}\text { Gomes et al. (2015); } \\
\text { Carvalho (2003) }\end{array}$ & $\begin{array}{l}\text { Almeida and Weber (2005); } \\
\text { Carvalho (2003); Gomes et al., } \\
(2015,2016)\end{array}$ \\
\hline
\end{tabular}

TSI Trophic State Index; NF not found. 
effluents, deforestation and uncontrolled soil occupation (Gomes et al., 2015). Samples were collected in the Taquacetuba branch (Bil $23^{\circ} 48^{\prime} 16.5^{\prime \prime} \mathrm{S}, 46^{\circ} 38^{\prime} 33.26^{\prime \prime} \mathrm{W}$ ), a region of large importance as a water supply for São Paulo city, considered hypereutrophic due to pollution by metals and frequent cyanobacterial blooms identified in previous studies (Table 1 ).

\subsection{Animals and experimental design}

The study was conducted from 2012 to 2014, sampling during each season, according to the following criteria: in 2012, the sampling period occurred between January and December, characterized by the capture of A. fasciatus females. During 2013-2014, the sampling period was held between September 2013 and March 2014, capturing both males and females. From those captures, the following groups were defined according to the seasons: Sum/12 (January to March 2012); Fal/12 (April to June 2012); Win/12 (August 2012); Spr/12 (October and December 2012); Win/13 (August 2013); Spr/13 (October and December 2013); Sum/14 (January to March 2014). A total of 162 females (body mass $15.2 \pm 4.1 \mathrm{~g}$, total length $10.3 \pm 0.8 \mathrm{~cm}$ ) and 72 males (body mass $12.3 \pm 2.6 \mathrm{~g}$, total length $10.0 \pm 0.8 \mathrm{~cm}$ ) were caught. Captures were authorized by the Federal Agency System ("Sistema de Autorização e Informação em Biodiversidade"; SISBIO 31935).

At the collection site, fish were anesthetized with $0.1 \%$ benzocaine. Total weight and length and gonad weight were measured. Blood samples were obtained by puncture of the caudal vein using heparinized syringes, and then centrifuged $(655.1 \mathrm{~g}$ ) for $5 \mathrm{~min}$ to obtain plasma. Animals were then euthanized by decapitation, as was approved by the Animal Ethics Committee of the Institute of Biosciences, University of São Paulo (Protocol N ${ }^{\circ}$ 154/2012). Liver and gonads were quickly removed and immediately weighed for calculation of the hepatosomatic and gonadosomatic indexes (HSI and GSI) (HSI = [liver mass/body mass]x100; GSI = [gonad mass/body mass]x100). A portion of the gonad was fixed in Bouin's solution for histological analysis. Another portion of known mass was placed in Gilson's solution for fecundity analysis (Vazzoler, 1981). The stages of oocyte maturation were classified according to Dias et al. (1998) and Honji et al. (2006). Plasma and liver tissue samples were stored on dry ice, then transported to the laboratory and stored at $-80^{\circ} \mathrm{C}$ for further analysis.

\subsection{RNA extraction and reverse transcriptase-polymerase chain reaction (RT-PCR)}

Hepatic gene expression of vitellogenin A (VTG-A; Finn and Kristoffersen, 2007) and estrogen receptor alpha (ER $\alpha)$ were quantified by RT-qPCR. Total RNA was isolated by the RNeasy ${ }^{\circledR}$ mini total RNA isolation kit (Qiagen ${ }^{\circledast}$ ) according to the manufacturer's protocol. RNA purity was assessed spectrophotometrically (NanoDrop1000; Thermo Fisher Scientific) and RNA integrity was evaluated by determining the ratio of $28 \mathrm{~S}$ and $18 \mathrm{~S}$ ribosomal RNA abundance with RNA $6000 \mathrm{Na}-$ nokit (Agilent Technologies ${ }^{\circledR}$ ). Contaminating genomic DNA was removed with DNase using the DNA-free Turbo kit (Life Technologies ${ }^{\circledR}$ ). One microgram of RNA was used for cDNA synthesis by reverse transcriptase using the Quanti Tect Reverse Transcription Kit (Qiagen ${ }^{\circledR}$ ).

PCR was used to amplify partial cDNA sequences for VTG-A and $\mathrm{ER} \alpha$ using primers designed against conserved regions of Astyanax mexicanus and some Cypriniformes. Each reaction consisted of $2.5 \mu \mathrm{L}$ of Ecotaq Buffer (10X) with Mg (Lucigen $\left.{ }^{\circledR}\right), 18.3 \mu \mathrm{L}$ of water, $1 \mu \mathrm{L}$ of $10 \mathrm{nM}$ deoxynucleotide Mix Solution (dNTP) for each dNTP (BioLabs ${ }^{\circledR}$ ), $1 \mu \mathrm{L}$ of each primer and $0.2 \mu \mathrm{L}$ of Ecotaq DNA Polymerase $100 \mathrm{U}$ to $5 \mathrm{U} / \mu \mathrm{L}$ (Lucigen). The amplification protocol with the thermalcycler was programmed a $90^{\circ} \mathrm{C}(60 \mathrm{~s})$, followed by a $40{ }^{\circ} \mathrm{C}$ cycle $(10 \mathrm{~s}), 60^{\circ} \mathrm{C}(0.30 \mathrm{~s})$, $72{ }^{\circ} \mathrm{C}(60 \mathrm{~s})$ and $72^{\circ} \mathrm{C}(5 \mathrm{~min})$. PCR products were separated through electrophoresis on 1\% agarose gel and purified using the QIA quick PCR Clean up Kit (QIAGEN ltd.). Primers for the $18 \mathrm{~s}$ ribosomal RNA gene
Table 2

Primers used for quantitative reverse-transcriptase PCR.

\begin{tabular}{lll}
\hline Genes & Primer & DNA sequence \\
\hline VTG & Forward & GCCTCTGCGTTGTTGATCTT \\
VTG & Reverse & AAACTCTGACCCTGCTGGAA \\
ER $\alpha$ & Forward & CAGGACATGTACACTGCAGC \\
ER & Reverse & GGTTGGTTGCTGGACACA \\
$18 \mathrm{~S}$ rRNA & Forward & CCCTATCAGCTGTCGATGGT \\
$18 \mathrm{~S}$ rRNA & Reverse & TTACAGGGCCTCGAAAGAGA \\
\hline
\end{tabular}

(housekeeping used as a normalizer) were designed using the published sequence for A. fasciatus (genbank KJ129623.1).

\subsubsection{Real-time quantitative assays ( $R T-q P C R$ )}

The primers designed and used for RT-qPCR are shown in Table 2. Genes were quantified using the Stratagene MX3000P real time PCR system using delta-delta Ct (normalized and relative quantification). Each reaction contained $2 \mu \mathrm{L}$ of sample (dilution $1: 10$ ), $12.5 \mu \mathrm{L}$ of Power SYBR Green PCR Master Mix, $8.5 \mu \mathrm{L}$ of water and $1 \mu \mathrm{L}$ of primers. The thermos cycling schedule started at $95^{\circ} \mathrm{C}(15 \mathrm{~min})$ followed by 40 cycles of $95^{\circ} \mathrm{C}(10 \mathrm{~s}), 60^{\circ} \mathrm{C}(0.30 \mathrm{~s}), 72^{\circ} \mathrm{C}(60 \mathrm{~s})$, and a melt curve cycle at $95^{\circ} \mathrm{C}(60 \mathrm{~s}), 55^{\circ} \mathrm{C}(0.30 \mathrm{~s}), 95^{\circ} \mathrm{C}(0.30 \mathrm{~s})$. The standard curve, constructed by the PCR products of interest, showed a linear relationship for the Ct values (cycle threshold). Based on the slope of the curve, the efficiency of the PCR was calculated as $111.9 \%, 99.8 \%$ and $95.5 \%$ for VTG-A, ER $\alpha$ and $18 \mathrm{~S}$, respectively.

\subsection{7ß-estradiol levels}

Plasma concentration analysis of $17 \beta$-estradiol (E2) was performed using ELISA immunoassay kits $\left(\right.$ Cayman $^{\circledR}$ ), following the manufacturer's guidelines. The microplate reader (Spectra Max250, Molecular Devices) was at a wave length of $450 \mathrm{~nm}$. Samples were diluted 5 times with buffer solution from the kit. The lower limit of detection was $15 \mathrm{pg} / \mathrm{mL}$. The minimum and maximum intervals of intraspecific and interspecific coefficients of variation (CV) were $2.2-19.2 \%$ and $0.67-0.57 \%$, respectively.

\subsection{Histological analysis}

Gonad samples were dehydrated through an ascending series of ethanol solutions, cleared in dimethylbenzene and embedded in Paraplast $^{\circledR}$ (Erv-Plast, Erviegas) following routine for histological procedures. Samples were serially sectioned at $5 \mu \mathrm{m}$ on a microtome (Leica RM2255), mounted on Poly-L-lysine covered slides (Sigma, USA) and stained with haematoxylin-eosin or Periodic-Acid-Schiff (PAS)/ Weigert's Haematoxylin/Metanil Yellow (Quintero-Hunter et al., 1991). Sections were analyzed and photographed using a computerized image capture system (microscope Leica DM1000, photographic camera Leica DFC295, and image capture Leica Application Suite Professional software, LAS V3.6). Stages of oogenesis were classified according Prado et al. (2011) and based on different stages of oocyte development, maturation stages of the ovary were adapted and established in accordance with Dias et al. (1998) and Honji et al. (2006).

\subsection{Fecundity and diameter of oocytes}

In order to determine absolute fecundity (AF; the number of oocytes released by a female in each spawning cycle) (Vazzoler, 1996), onethird of the gonad was weighed and placed in Gilson's solution for 30 days, allowing oocyte dissociation. Later, oocytes were transferred to $70^{\circ} \mathrm{GL}$ and the volume was adjusted to $1 \mathrm{~L}$. A sample of $2.5 \mathrm{~mL}$ of oocyte solution was collected using a Stempel pipette, and the number of oocytes were then counted. For each individual, AF was calculated using three sub-samples of oocyte solution divided by total ovarian mass (RF; 
relative fecundity). Oocyte diameter was measured using the same image capture program mentioned in the histological section. Percentage of residual oocytes (RO) and vitellogenic oocytes (VO) were estimated.

\subsection{Statistical analysis}

Data were expressed as mean \pm SEM (standard error of the mean). Comparisons of animals between both environmental sites sampled throughout the year were performed by two-way analysis of variance (ANOVA), followed by the Holm-Sidak multiple comparison test. The significance level adopted was $95 \%(\mathrm{P} \leq 0.05)$. Statistical analyses were performed using the software SigmaStat for Windows, version 3.5 (Systat Software, San Jose, CA, USA).

\section{Results}

\subsection{Gene expression of VTG-A and ER $\alpha$}

Gene expression of VTG-A showed a significant increase during Sum/14 in females from Bil reservoir compared to those sampled during the other seasons from PN reservoir $(\mathrm{P}<0.001$; Table 3$)$. This difference was not observed in case of ER $\alpha$ gene expression. Males from Bil showed a very large inter individual variability of gene expression of $\mathrm{ER} \alpha(\mathrm{P}=0.933)$ and VTG-A $(\mathrm{P}=0.258)$ although no statistically differences were observed (Table 3 ).

\subsection{E2 concentration}

Concentration of plasma E2 did not vary between females throughout the different seasons sampled $(\mathrm{P}=0.173$ and $\mathrm{P}=0.357$, respectively; Table 3) nor between the $\mathrm{PN}$ and Bil reservoirs $(\mathrm{P}=$ 0.134). In contrast, males in the Bil reservoir presented a higher plasma E2 concentration during Spr/13 $(\mathrm{P}<0.001)$ compared to males from PN $(\mathrm{P}<0.001$; Table 3).

\subsection{Gonadal histology}

Histological analysis showed that ovaries, from both PN and Bil reservoirs, were in an advanced stage of maturity. In relation to the stage of oocytes development, there was a higher frequency of vitellogenic oocytes, followed by perinucleolar oocytes and cortical alveoli oocytes in females from both reservoirs throughout the year (Table 4). Atretic oocytes were only observed in Spr/12, Spr/13 and Sum/14 in females from the PN reservoir and in Sum/12 in animals from the Bil reservoir (Table 4). Histological analysis of the ovaries of females from both reservoirs allowed the identification of oogonia (Fig. 1A), cortical alveoli oocytes (Fig. 1B), perinucleolar oocytes (Fig. 1C), vitellogenic oocytes with a central nucleus (Fig. 1D), vitellogenic oocytes with nuclear migration (Fig. 1E) and atretic oocytes (Fig. 1F).

Table 3

Gonadosomatic Index (GSI, \%), Hepatosomatic Index (HSI, \%), Absolute and Relative Fecundity (AF and RF), Residual and Vitellogenic Oocytes (RO and VO) of $A$. fasciatus females and $17 \beta$-estradiol (E2, pg mL ${ }^{-1}$ ) and expression of vitellogenin (VTG) and estrogen receptor (ER $\alpha$ ) genes of females and males of $A$. fasciatus (Mean \pm SEM).

\begin{tabular}{|c|c|c|c|c|c|c|c|}
\hline & Sum/12 & Fal/12 & Win/12 & Spr/12 & Win/13 & Spr/13 & Sum/14 \\
\hline \multicolumn{8}{|l|}{ Females } \\
\hline GSI - PN & $11.0 \pm 0.89^{\mathrm{ab}}$ & $6.9 \pm 0.53^{\mathrm{c}}$ & $6.1 \pm 0.63^{\mathrm{c}}$ & $13.3 \pm 0.82^{\mathrm{a}}$ & $6.4 \pm 0.63^{\mathrm{c}}$ & $11.3 \pm 0.70^{\mathrm{ab}}$ & $7.6 \pm 0.93^{\mathrm{b}}$ \\
\hline GSI - Bil & $11.1 \pm 0.85$ & $8.8 \pm 0.66$ & $10.3 \pm 0.21^{*}$ & $10.7 \pm 0.91$ & $9.5 \pm 0.96^{*}$ & $9.4 \pm 1.19$ & $11.7 \pm 2.69^{*}$ \\
\hline HSI - PN & $1.2 \pm 0.24$ & $1.1 \pm 0.05$ & $1.7 \pm 0.58$ & $1.0 \pm 0.14$ & $1.3 \pm 0.22$ & $0.9 \pm 0.11$ & $0.9 \pm 0.14$ \\
\hline HSI - Bil & $0.7 \pm 0.04$ & $1.1 \pm 0.14$ & $10.7 \pm 0.85$ & $0.7 \pm 0.05$ & $1.0 \pm 0.10$ & $0.9 \pm 0.16$ & $0.8 \pm 0.07$ \\
\hline AF - PN & $8056.5 \pm 1113.74$ & $8289.4 \pm 1395.6$ & $1443.6 \pm 375.30$ & $7542.0 \pm 1391.11$ & $2823.5 \pm 1731.59$ & $6630.9 \pm 1731.59$ & $5347.2 \pm 966.86$ \\
\hline AF - Bil & $\begin{array}{l}12988.9 \pm \\
2189.30^{\mathrm{b}}\end{array}$ & $\begin{array}{l}11153.6 \pm \\
1890.45^{\mathrm{b}}\end{array}$ & $3097.2 \pm 780.47^{b}$ & $\begin{array}{l}4867.8 \pm \\
1073.99^{\mathrm{b}}\end{array}$ & $\begin{array}{l}25385.7 \pm \\
8226.28^{\mathrm{ab}^{* /}}\end{array}$ & $\begin{array}{l}61322.3 \pm \\
16873.90^{\mathrm{a}^{*}}\end{array}$ & $1972 \pm 787.48^{\mathrm{b}}$ \\
\hline RF - PN & $4272.9 \pm 294.84$ & $4601.2 \pm 456.30$ & $2330.2 \pm 473.07$ & $3798.2 \pm 505.03$ & $3678.6 \pm 910.86$ & $3762.2 \pm 287.11$ & $3847.8 \pm 910.86$ \\
\hline RF - Bil & $6098.1 \pm 893.91^{b}$ & $\begin{array}{l}9094.8 \pm \\
3472.03^{\mathrm{b}}\end{array}$ & $2269.7 \pm 402.04^{\mathrm{b}}$ & $3104.0 \pm 431.78^{b}$ & $\begin{array}{l}18043.3 \pm \\
7818.92^{\mathrm{ab}^{*}}\end{array}$ & $\begin{array}{l}43322.8 \pm \\
10176.49^{\mathrm{a}^{*}}\end{array}$ & $1166.9 \pm 393.81^{b}$ \\
\hline RO - PN & $79.2 \pm 2.41$ & $83.1 \pm 7.28$ & $89.4 \pm 6.09$ & $77.1 \pm 9.30$ & $84.6 \pm 3.77$ & $81.2 \pm 2.43$ & $85.6 \pm 1.13$ \\
\hline RO - Bil & 79.2. \pm 5.11 & $83.1 \pm 13.23$ & $89.4 \pm 1.20$ & $77.1 \pm 3.23$ & $83.7 \pm 2.66$ & $77.4 \pm 4.41$ & $83.8 \pm 8.10$ \\
\hline VO - PN & $20.7 \pm 2.85$ & $12.3 \pm 1.80$ & $9.0 \pm 0.41$ & $23.0 \pm 5.75$ & $17.2 \pm 4.81$ & $19.5 \pm 2.26$ & $14.9 \pm 1.01$ \\
\hline VO - Bil & $22.1 \pm 5.74$ & $12.0 \pm 3.23$ & $8.8 \pm 2.00$ & $11.0 \pm 3.23$ & $16.0 \pm 2.25$ & $22.7 \pm 4.47$ & $16.2 \pm 8.10$ \\
\hline E2 - PN & $200,2 \pm 33,13$ & $104,4 \pm 10,37$ & $134,2 \pm 18,62$ & $50,1 \pm 10,58$ & $256,2 \pm 109,46$ & $101,2 \pm 20,30$ & $299,3 \pm 123,72$ \\
\hline E2 - Bil & $78,3 \pm 9,74$ & $218,6 \pm 47,43$ & $101,2 \pm 24,87$ & $168,6 \pm 53,89$ & $146,1 \pm 20,65$ & $886,7 \pm 543,17$ & $241,2 \pm 45,32$ \\
\hline VTG (mRNA) - PN & & & $\begin{array}{l}1.4 \pm 0.45(n= \\
4)\end{array}$ & $1 \pm 0.10(n=2)$ & $1.3 \pm 0.36(n=6)$ & $3.0 \pm 1.98(n=5)$ & $1.2 \pm 0.75(n=5)$ \\
\hline VTG (mRNA) - Bil & & & $\begin{array}{l}0.6 \pm 0.36^{\mathrm{b}}(n= \\
\text { 4) }\end{array}$ & $\begin{array}{l}0.7 \pm 0.17^{\mathrm{b}}(n= \\
6)\end{array}$ & $1.0 \pm 0.35^{\mathrm{b}}(n=4)$ & $0.5 \pm 0.30^{\mathrm{b}}(n=6)$ & $\begin{array}{l}255.9 \pm 96.48^{\mathrm{a}^{*}}(n= \\
6)\end{array}$ \\
\hline ER $\alpha$ (mRNA) - PN & & & $\begin{array}{l}1.1 \pm 0.29(n= \\
4)\end{array}$ & $1.0 \pm 0.17(n=2)$ & $1.5 \pm 0.54(n=6)$ & $1.9 \pm 0.88(n=5)$ & $1.2 \pm 0.33(n=5)$ \\
\hline ER $\alpha$ (mRNA) - Bil & & & $\begin{array}{l}0.8 \pm 0.32(n= \\
\text { 4) }\end{array}$ & $0.2 \pm 0.05(n=6)$ & $1.3 \pm 0.28(n=4)$ & $0.04 \pm 0.01(n=6)$ & $1.4 \pm 0.32(n=6)$ \\
\hline \multicolumn{8}{|l|}{ Males } \\
\hline E2 - PN & & & & & $172,2 \pm 92,023$ & $218,8 \pm 31,81$ & $351,0 \pm 68,16 b$ \\
\hline E2 - Bil & & & & & $268,1 \pm 61,65^{\mathrm{b}}$ & $1675,8 \pm 224,31^{\mathrm{a}^{*}}$ & $497,3 \pm 118,38^{b}$ \\
\hline VTG (mRNA) - PN & & & & & $6.0 \pm 5.64(n=4)$ & $6.2 \pm 5.30(n=5)$ & $1.5 \pm 1.41(n=6)$ \\
\hline VTG (mRNA) - Bil & & & & & $\begin{array}{l}911.6 \pm 706.2(n= \\
4)\end{array}$ & $5.4 \pm 2.61(n=4)$ & $0.7 \pm 0.30(n=3)$ \\
\hline ER $\alpha$ (mRNA) - PN & & & & & $1.1 \pm 0.24$ & $1.2 \pm 0.30$ & $1.4 \pm 0.50$ \\
\hline ER $\alpha$ (mRNA) - Bil & & & & & $1.4 \pm 0.37(n=4)$ & $0.7 \pm 0.40(n=4)$ & $3.2 \pm 0.60(n=3)$ \\
\hline
\end{tabular}

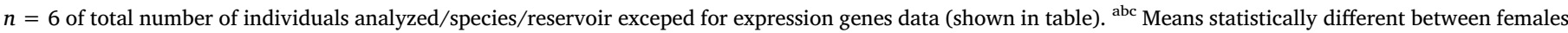

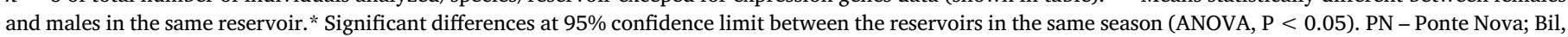

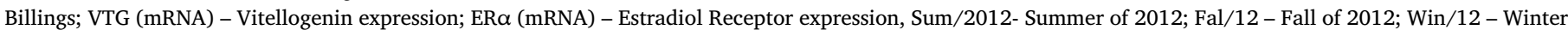

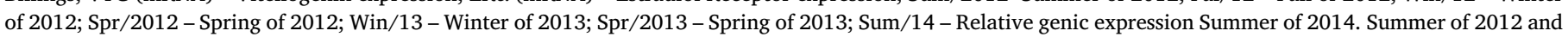
Fall of 2012 were not analyzed due absence of sample. 
Table 4

Classification of ovarian maturation stage based on oocyte development of A. fasciatus females.

\begin{tabular}{|c|c|c|c|c|c|c|c|c|c|c|c|}
\hline & \multicolumn{5}{|l|}{ PN } & \multicolumn{5}{|l|}{ Bil } & \multirow[t]{2}{*}{ Maturation Stage } \\
\hline & PNO & COA & vo & AO & POF & PNO & $\mathrm{COA}$ & vo & AO & POF & \\
\hline \multicolumn{12}{|l|}{ Females } \\
\hline Sum/12 & ++ & + & +++ & - & - & ++ & + & +++ & - & + & Advanced \\
\hline Fal/12 & ++ & + & +++ & - & - & ++ & + & +++ & - & - & Advanced \\
\hline Win/12 & ++ & + & +++ & - & - & ++ & + & +++ & - & - & Advanced \\
\hline Spr/12 & ++ & + & +++ & + & - & ++ & + & +++ & - & - & Advanced \\
\hline Win/13 & ++ & + & +++ & - & - & ++ & + & +++ & - & - & Advanced \\
\hline Spr/13 & ++ & + & +++ & + & - & ++ & + & +++ & - & - & Advanced \\
\hline Sum/14 & ++ & + & +++ & + & - & ++ & + & +++ & - & - & Advanced \\
\hline
\end{tabular}

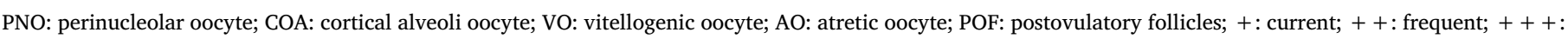
predominant;: absent.
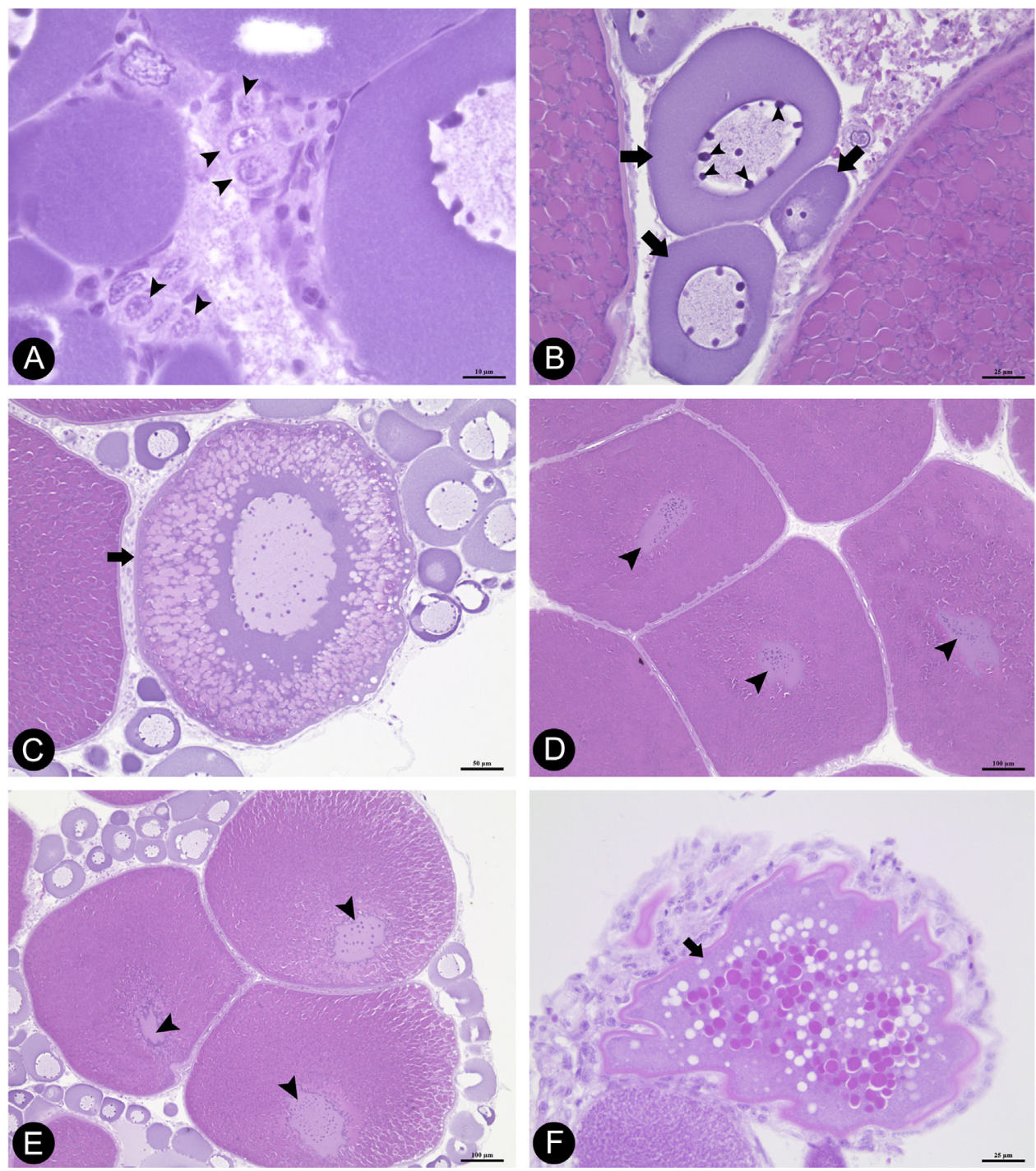

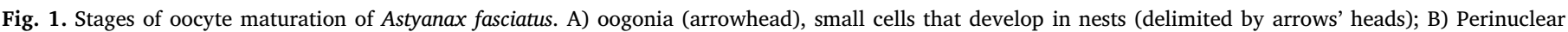

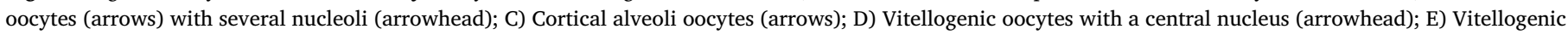

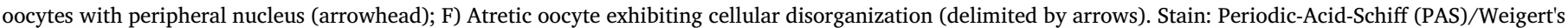
Haematoxylin/Metanil Yellow. Bar: $10 \mu \mathrm{m}$ (A), $25 \mu \mathrm{m}$ (B, F), $50 \mu \mathrm{m}$ (C); $100 \mu \mathrm{m}$ (D, E).

\subsection{GSI and HSI}

The GSI of females collected in the PN reservoir were higher in Spr/ 12 and Sum/12 than in Fal/12, Fal/13, Win/12 and Win/13 $(\mathrm{P}<0.001$, Table 3$)$. There was no statistical difference for females collected in the Bil reservoir throughout the seasons (Table 3). Related to the sampling sites, higher values of GSI were observed for females from Bil reservoir during Win/12, Win/13 and Sum/14 $(\mathrm{P}<0.001$, Table 3). No significant statistical differences were observed for HSI values between sampling sites and seasons (Table 3). 
Sum/12

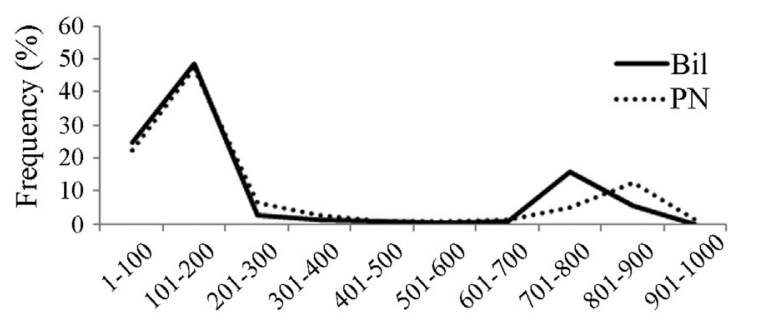

A

Oocyte diameter $(\mu \mathrm{m})$

Win/12

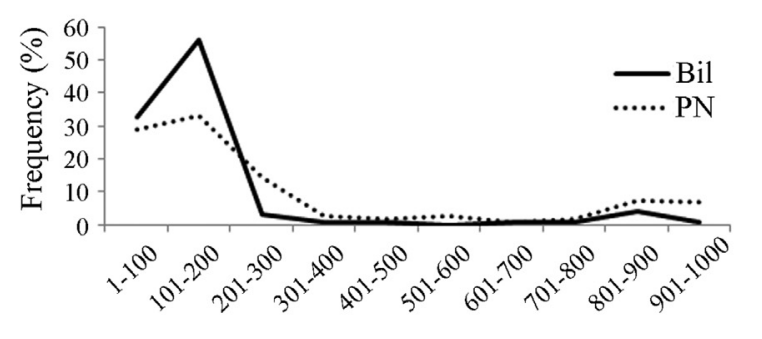

C

Oocyte diameter $(\mu \mathrm{m})$

Win/13

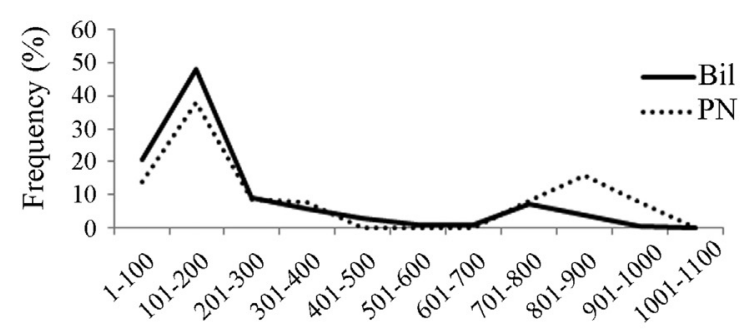

E Oocyte diameter $(\mu \mathrm{m})$
$\mathrm{Fal} / 12$

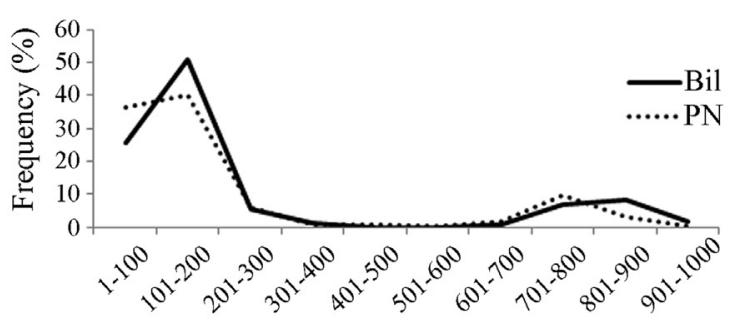

B

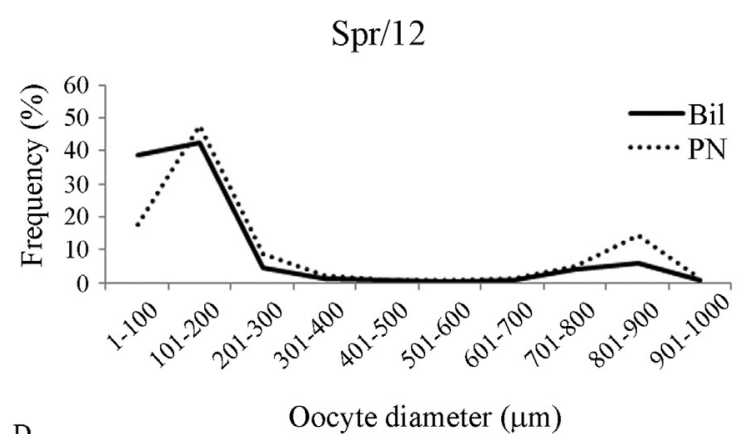

D

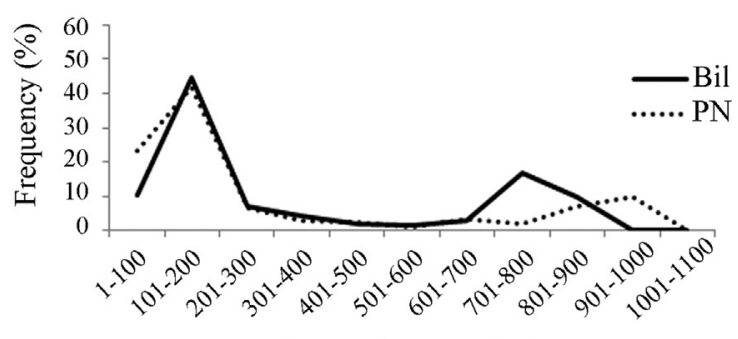

F Oocyte diameter $(\mu \mathrm{m})$

Sum $/ 14$

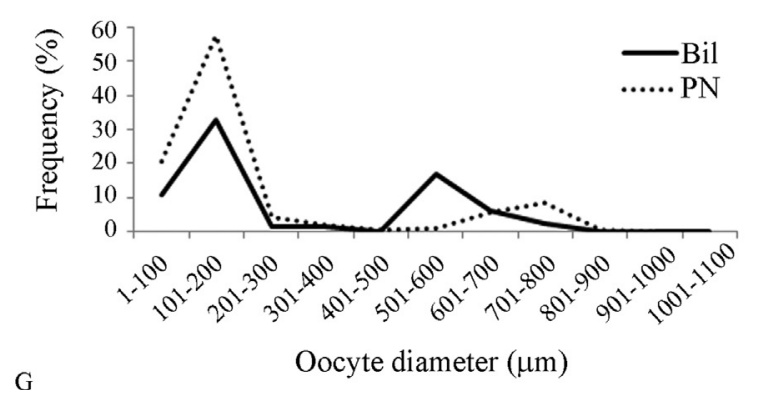

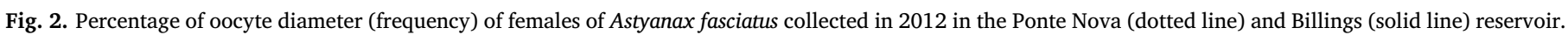

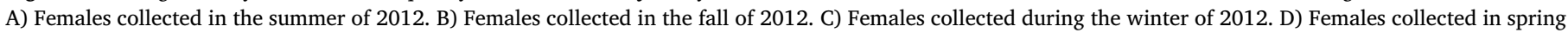

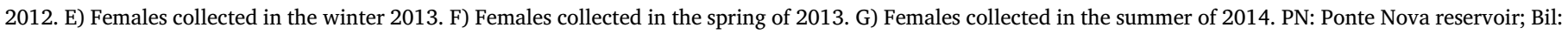

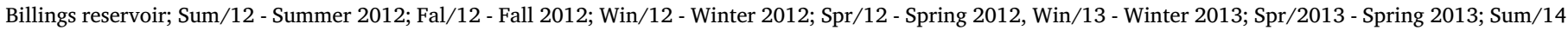
- Summer 2014.

\subsection{Fecundity and oocyte diameter}

Females from the Bil reservoir during Spr/13 showed the highest $\mathrm{AF}$, except for Win/13 ( $\mathrm{P}=0.030$; Table 3 ). No differences were found between seasons for females collected at the PN reservoir (Table 3). In relation to the reservoirs, females from Bil exhibited higher AF and RF values than those collected at PN during Win/13 and Spr/13 ( $\mathrm{P}=0.05$ and $\mathrm{P}=0.010$, respectively) (Table 3 ). The percentage of $\mathrm{RO}$ and $\mathrm{OV}$ did not show any statistical differences between females collected in either site, neither throughout the year (Table 3). Finally, females in both sampling sites and throughout the year showed a higher diameter frequency of OR and lower of OV (Fig. 2).

\section{Discussion}

In the present study, the reproductive physiology of $A$. fasciatus was evaluated using biomarkers related to the gonadal maturation process to determine the effects of diminished water quality by anthropogenic 
impact of a major urban reservoir in Brazil. Molecular biomarkers, such as ER $\alpha$ and VTG-A gene expression, biochemical parameters, such as plasma concentration of E2, and morphological characteristics, such as gonadal morphology and oocyte recruitment dynamics (AF, RF and diameter) generated differing responses, evidence that fish possess diverse regulatory abilities, even in adverse environmental conditions. In addition, the physiological responses of males and females of $A$. fasciatus occurred at specific moments, which may be a consequence of the seasonal variation in the presence of contaminants in the Bil reservoir and/or their mode of action (MoA), defined as the series of key processes that begin with the interaction of a contaminant with a target site (e.g. receptor) and proceeds through operational and anatomical changes in an organism that result in sub lethal or lethal effects (USEPA, 2000; Beyer et al., 2014).

Gene expression of VTG-A, biomarker of estrogen exposure, showed alterations in females at distinct seasons. In females, during Sum/14 the mean value of gene expression was well above that of others seasons sampled. This suggests environmental interference and the presence of estrogenic compounds in Bil at that time. A similar outcome with this biomarker was found by Cocci et al. (2017), who studied Gilthead seabream (Sparus aurata) hepatocytes exposed to seawater extracts, showing a correlation between presence of polychlorinated biphenyls (PCBs) and polycyclic aromatic hydrocarbons (PAHs) in seawater and VTG gene expression. Although females seem to adjust their cycle to different environments, the fact that males exhibit evidences of VTG gene expression and high levels of E2 (Win/12-13), clearly reflect the presence of xenobiotics, acting as estrogens, in Bil reservoir, reinforcing the notion that the presence of EDCs in the Bil reservoir can be interfering with reproductive processes of $A$. fasciatus.

These EDCs may also explain the results of AF and RF in females from this reservoir, which were higher in Win/13 and Spr/13 in relation to the other seasons of the year and to females from the PN reservoir. The diverse alterations for different parameters at different sampling seasons (E2 concentration, AF, RF and VTG-A mRNA in females) may be the result of a complex mix of contaminants in the environment. A study with female zebrafish (Danio rerio) evaluated the interaction of contaminants in a complex mixture, and showed several alterations with exposure to a single dose of 17a-ethinylestradiol (EE2), with changes of steroid acute regulatory protein (StAR), 17b-hydroxysteroid dehydrogenase type 1 (17b-HSD1) and aromatase (cyp19a1), whereas exposure to a mixture of eleven estrogenic compounds previously quantified at the Douro River estuary (Portugal), only caused differences at cyp19a1 (Urbatzka et al., 2012). Chemical contaminants, whether with similar or different MoA, may influence the toxicity of another compound, resulting in interactive effects, such as additive, synergistic or antagonistic (Beyer et al., 2014). An efficient way of assessing the effects of mixtures is the weight-of-evidence approach (Sanchez and Porcher, 2009), which proposes the need for multiple studies, both in the field and in the laboratory, in order to understand more precisely how these compounds are capable of affecting the biota.

The annual variation pattern of GSI from females sampled in the PN reservoir was different from that observed in the Bill reservoir animals. Prado et al. (2011) studied A. fasciatus in five distinct reservoirs in the South eastern region of Brazil (one of them considered uncontaminated and the others contaminated) and showed that females at all reservoirs presented lower GSI values in July (winter) and higher in October (spring). The results of the present study for the PN reservoir are in agreement with these data and as discussed by these authors, variables other than the presence of contaminants can influence the GSI, such as food availability, genetic profile, abundance of predators and environmental status. Furthermore, the pattern of GSI seasonal change may be related to the life history of the population in a particular reservoir, taking into account the reproductive plasticity already reported for this species (Silva et al., 2010). Both GSI and ovarian histology are widely used as biomarkers in studies investigating the role of environmental variables on the oocyte maturation process, together with the synthesis of vitellogenin and the presence of intersex individuals, both in the natural environment and in the laboratory (Bjerregaard et al., 2006; Jobling et al., 2006; Harris et al., 2011; Lange et al., 2011; Tetreault et al., 2011; Bahamonde et al., 2014). In this study, no change was observed in gonadal histomorphology, even when alterations were found at other biomarkers of exposure at different levels of organization, associated with physiological, genetic and/or biochemical mechanisms. These results point to regulatory mechanisms that minimize the effect of the observed changes in these biomarkers at the histomorphological level.

Taken together, the results found in this study suggest that EDCs present in the Bil reservoir mainly influenced those biomarkers of biological effects, mainly regarding the results found in males. Dang (2016), reviewing several studies with EDCs on biomarkers of exposure and effect, such as vitellogenin concentration, secondary sex characteristics and sex ratio in $P$. promelas, Oryzias latipes and D. rerio, mentions that changes in biomarkers result of a multifactorial sequence of complex processes that may be influenced by chemical, non-chemical, isolated biological factors and other interactions. This assertion can be corroborated in this study, because after data collection during a long period, the animals exhibited alterations at specific moments in biomarkers of exposure, possibly caused by different contaminants and/ or MoA. As stated by Cortes et al. (2016), this study reinforces the importance of including different biomarkers for assessing risk analysis. In addition, we believe that the continued reassessment of these risk analyses should be considered, especially in areas susceptible to varying environmental or anthropogenic contamination, such as locations close to urban centers.

\section{Conclusion}

The use of different biomarkers allowed not only to describe the alterations on the physiological processes involved in reproduction in A. fasciatus using different biomarkers at various levels of organization, but also to confirm the presence and effects of EDC in a natural environment with heavily anthropogenic influence. The conditions found in the water from the Bil reservoir interfered on biomarkers of biological effects (plasma concentration of $\mathrm{E} 2, \mathrm{AF}$ and $\mathrm{RF}$ ) in A. fasciatus. Additionally, presence of biomarkers of exposure (VTG-A gene expression in males) supports the hypothesis that EDCs present in this water body are interfering with estrogenic activity in $A$. fasciatus. On the other hand, the histomorphological data and frequency of ovarian maturation stages indicate that there was not damage to the process of oocyte maturation process and how it may reflect in the population dynamics. The next step is to study deeply the origin, nature and mechanisms of the alterations produced by pollutants of emerging concern and, secondly, to provide solid evidence for incorporation into national regulatory regulations.

\section{Acknowledgements}

This work was supported by FAPESP (Fundação de Amparo à Pesquisa do Estado de São Paulo) [Research Grant: 12/50371-2, a Ph.D. scholarship: 2011/15453-5 and a scholarship stage through the International Research Project: 2014/01866-4] FAPESP-CONICET (Consejo Nacional de Investigaciones Científicas y Técnicas, Argentina) [2013/50480-9]. We thank the Laboratorio de Ecotoxicología Acuática at Universidad de Buenos Aires, Argentina; and Contaminant Biogeochemistry and Environmental Toxicology group of Common Wealth Scientific and Industrial Research Organization at Adelaide, Australia. The authors also thank the fishermen (Evaldo Bizarrias and Milton Nunes de Santana), and the LAMEROA team for their help with sampling and IB/USP for providing logistics and facilities for the study. 


\section{References}

Alberto, A., Camargo, A.F.M., Verani, J.R., Costa, O.F.T., Fernandes, M.N., 2005. Health variable sand gill morphology in the tropical fish Astyanax fasciatus from a sewagecontaminated river. Ecotoxicol. Environ. Safe 61, 247-255. https://doi.org/10.1016/ j.ecoenv.2004.08.009.

Almeida, G.A., Weber, R.R., 2005. Fármacos na represa Billings. Rev. Saúde Amb. 6, 7-13.

Bahamonde, P.A., Fuzzen, M.L., Bennett, C.J., Tetreault, G.R., McMaster, M.E., Servos, M.R., Martyniuk, C.J., Munkittrick, K.R., 2014. Whole organism responses and intersex severity in rainbow darter (Etheostoma caeruleum) following exposures to municipal waste water in the Grand River Basin on Canada. Part A. Aquat. Toxicol. 159, 290-301. https://doi.org/10.1016/j.aquatox.2014.11.023.

Baroiller, J.F., Guiguen, Y., 2001. Endocrine and environmental aspects of sex differentiation in gonochoristic fish. Cell. Mol. Life Sci. 91, 177-201. https://doi.org/10. $1007 / \mathrm{s} 000180050344$

Beyer, J., Petersen, K., Song, Y., Ruus, A., Grung, M., Bakke, T., Tollefsen, K.E., 2014. Environmental risk assessment of combined effects in aquatic ecotoxicology: a discussion paper. Mar. Environ. Res. 96, 81-91. https://doi.org/10.1016/j.marenvres. 2013.10.008.

Bjerregaard, L., Madsen, A., Korsgaard, B., Bjerregaard, P., 2006. Gonad histology and vitellogenin concentrations in brown trout (Salmo trutta) from Danish Streams impacted by sewage effluent. Ecotoxicology 15, 315-327. https://doi.org/10.1007/ s10646-006-0061-9.

Broerg, K., Westernhagen, H.V., Zander, S., Korting, W., Koehler, A., 2005. The "bioeffect assessement index" (BAI): a concept for the quantification of effects of marine pollution by an integrated biomarker approach. Mar. Poll. Bull. 50, 495-503. https:// doi.org/10.1016/j.marpolbul.2005.02.042.

Carrasco-Letelier, L., Eguren, G., Mello, F.T., Groves, P.A., 2006. Preliminary field study of hepatic porphyrin profiles of Astyanax fasciatus (Teleostei, Characiformes) to define anthropogenic pollution. Chemosphere 62, 1245-1252. https://doi.org/10. 1016/j.chemosphere.2005.07.005.

Castro, P.M.G., Silva, M.E.P.A., Maruyama, L.S., Paiva, P., 2009. Produção Pesqueira do reservatório Billings (Alto Tietê - SP) nos anos de 2005, 2006 e 2007. Série. Rel. Técnicos Inst. De. Pesca 38, 1-10.

Carvalho, M.C., 2003. Comunidade fitoplanctônica como instrumento de biomonitoramento de reservatórios do Estado de São Paulo (Ph.D. thesis). São Paulo University.

CETESB, 1996. Avaliação do Complexo Billings: Comunidades Aquáticas, água e Sedimento (out. 1992 a out. 1993). Companhia Ambiental do Estado de São Paulo. Secretariado Meio Ambiente do Estado de São Paulo, São Paulo.

Cocci, P., Capriotti, M., Mosconi, G., Campanelli, A., Frapiccini, E., Marini, M., Caprini, G., Sagratini, G., Aretusi, G., Palermo, F.A., 2017. Alterations of gene expression indicating effects on estrogen signaling and lipid homeostasis in seabream hepatocytes exposed to extracts of seawater sampled from a coastal area of the central Adriatic Sea (Italy). Mar. Environ. Res. 123, 25-37. https://doi.org/10.1016/j. marenvres.2016.11.001.

Cortes, R., Hughes, S., Coimbra, A., Monteiro, S., Pereira, V., Lopes, M., Pereira, S., Pinto, A., Sampaio, A., Santos, C., Carrola, J., Jesus, J., Varanda, S., 2016. A multiple index integrating different levels of organization. Ecotox. Environ. Safe 132, 270-278. https://doi.org/10.1016/j.ecoenv.2016.06.001.

Dang, Z.C., 2016. Interpretation of fish biomarker data for identification, classification, risk assessment and testing of endocrine disrupting chemicals. Environ. Int. 92-93, 422-441. https://doi.org/10.1016/j.envint.2016.04.003.

Dias, A.C.V., Gomes, F.W., Bila, D.M., Sant'Anna, G.L., Dezotti, M., 2015. Analysis of estrogenic activity in environmental waters in Rio de Janeiro state (Brazil) using the yeast estrogen screen. Ecotox. Environ. Safe 120, 41-47. https://doi.org/10.1016/j. ecoenv.2015.05.013.

Dias, J.F., Peres-Rio, E., Chaves, P.T.C., Rossi-Wongtschowski, C.L.D.B., 1998. Análise macroscópica dos ovários de teleósteos: problemas de classificação e recomendações de procedimentos. Rev. Bras. Biol. 58, 55-59.

Driessnack, M.K., Matthews, A.L., Raine, J.C., Niyogi, S., 2016. Interactive effects of chronic waterborne copper and cadmium exposure on tissue-specific metal accumulation and reproduction in fathead minnow (Pimephales promelas). Comp. Biochem. Phys. C 179, 165-173. https://doi.org/10.1016/j.cbpc.2015.10.009.

Fernandes, D., Schnell, S., Porte, C., 2011. Can pharmaceuticals interfere with the synthesis of active androgens in male fish? An in vitro study. Mar. Pollut. Bull. 62, 2250-2253. https://doi.org/10.1016/j.marpolbul.2011.07.011.

Finn, R.N., Kristoffersen, B.A., 2007. Vertebrate vitellogenin gene duplication in relation to the "3R Hypothesis": correlation to the pelagic egg and the oceanic radiation of teleosts. PLoS ONE 2 (1), e169. https://doi.org/10.1371/journal.pone.0000169.

Flick, R.W., Bencic, D.C., See, M.J., Biales, A.D., 2014. Sensitivity of the vitellogenin assay to diagnose exposure of fathead minnows to $17 \alpha$-ethynylestradiol. Aquat. Toxicol. 152, 353-360. https://doi.org/10.1016/j.aquatox.2014.04.026.

Gomes, A.D., Tolussi, C.E., Ribeiro, C.S., Honji, R.M., Moreira, R.G., 2015. The role of ovarian steroids in reproductive plasticity in Hoplias malabaricus (Teleostei: characiformes: Erythrinidae) in tropical reservoirs with different degrees of pollution. Gen. Comp. Endocrinol. 222, 1-10. https://doi.org/10.1016/j.ygcen.2014.10.008.

Gomes, A.D., Tolussi, C.E., Boëchat, I.G., Pompêo, M.L.M., Cortez, M.P.T., Honji, R.M. Moreira, R.G., 2016. Fatty acid composition of tropical fish depends on reservoir trophic status and fish feeding habit. Lipids 51, 1193-1206. https://doi.org/10. 1007/s11745-016-4196-z.

Gorga, M., Insa, S., Petrovic, M., Barcélo, D., 2015. Occurrence and spatial distribution of EDC sand related compounds in water sand sediments of Iberian rivers. Sci. Total Environ. 503-504, 69-86. https://doi.org/10.1016/j.scitotenv.2014.06.037.

Gurgel, H.C.B., 2004. Estrutura populacional e época de reprodução de Astyanax fasciatus (Curvier) (Characidae, Tetragonopterinae) do Rio Ceará Mirim, Poço Branco, Rio
Grande do Norte, Brasil. Rev. Bras. Zool. 21, 131-135.

Harris, C.A., Hamilton, P.B., Runnalls, T.J., Vinciotti, V., Henshaw, A., Hodgson, D., Coe, T.S., Jobling, S., Tyler, C.R., Sumpter, J.P., 2011. The consequences of feminization in breeding groups of wild fish. Environ. Health Persp. 119, 306-311. https://doi.org/ 10.1289/ehp.1002555.

Hassell, K., Pettigrove, V., Beresford, N., Jobling, S., Kumar, A., 2016. No evidence of exposure to environmental estrogens in two feral fish species sampled from the Yarra River, Australia: a comparison with northern hemisphere studies. Ecotox. Environ. Safe 131, 104-117. https://doi.org/10.1016/j.ecoenv.2016.05.004.

Honji, R.M., Vaz dos Santos, A.M., Rossi-Wongtschowski, C.L.D.B., 2006. Identification of the stages of ovarian maturation of the Argentine hake Merluccius hubbsi Marini, 1933 (Teleostei: Merluccius): advantages and disadvantages of the use of the macroscopic and microscopic scales. Neotrop. Ichthyol. 4, 329-337. https://doi.org/10.1590/ S1679-62252006000300004.

Hook, S.E., Gallagher, E.P., Batley, G.E., 2014. The role of biomarkers in the assessment of aquatic ecosystem health. Integr. Environ. Assess. Manag. 10, 327-341. https://doi. org/10.1002/ieam.1530.

Ji, K., Liu, X., Lee, S., Kceuang, S., Kho, Y., Giesy, J.P., Choi, K., 2013. Effects of nonsteroidal anti-inflammatory drugs on hormones and genes of the hypothalamic- pituitary-gonadaxis, and reproduction of zebrafish. J. Hazard. Mater. 254-255, 242-251. https://doi.org/10.1016/j.jhazmat.2013.03.036.

Jobling, S., Williams, R., Johnson, A., Taylor, A., Gross-Sorokin, M., Nolan, M., Tyler, C.R., Van Aerle, R., Santos, E., Brighty, G., 2006. Predicted exposures to steroid estrogens in U.K. rivers correlate with widespread sexual disruption in wild fish populations. Environ. Health Persp. 114, 32-39. https://doi.org/10.1289/ehp.8050.

Kellar, C.R., Hassel, K.L., Long, S.M., Myers, J.H., Golding, L., Rose, G., Kumar, A., Hoffmann, A.A., Pettigrove, V., 2014. Ecological evidence links adverse biological effects to pesticide and metal contamination in an urban Australian watershed. J. Appl. Ecol. 51, 426-439. https://doi.org/10.1111/1365-2664.12211.

Kinney, C.A., Furlong, E.T., Werner, S.L., Cahill, J.D., 2006. Presence and distribution of wastewater-derived pharmaceuticals in soil irrigated with reclaimed water. Environ. Toxicol. Chem. 25, 317-326. https://doi.org/10.1897/05-187R.

Lange, A., Paull, G.C., Hamilton, P.B., Iguchi, T., Tyler, C.R., 2011. Implications of persistent exposure to treated wastewater effluent for breeding in wild roach (Rutilus rutilus) populations. Environ. Sci. Technol. 45, 1673-1679. https://doi.org/10.1021/ es103232q.

Marceniuk, A.P., Hilsdorf, A.W.S., 2010. Peixes das cabeceiras do Rio Tietê e Parque das Neblinas. Ócsso Des., São Paulo 160.

Mariani, C.F., Pompêo, M.L.M., 2008. Potentially bioavailable metals in sediment from a tropical polymictic environment Rio Grande Reservoir, Brazil. J. Soils Sediment 8, 248-288.

Minh, T.L.T., Phuoc, D.N., Quoc, T.D., Ngo, H.H., Lan, C.D.H., 2016. Presence of EDCs in surface water and effluents of pollution sources in Sai Gon and Dong Nai river basin. Sustain. Environ. Res. 26, 20-27. https://doi.org/10.1016/j.serj.2015.09.001.

Moncaut, N., Lo Nostro, F., Maggese, M.C., 2003. Vitellogenin detection in surface mucus of the South American cichlid fish Cichlasoma dimerus (Heckel, 1840) induced by estradiol-17ß. Effects on liver and gonads. Aquat. Toxicol. 63, 127-137.

Moschini-Carlos, V.M., Freitas, L.G., Pompêo, M., 2010. Limnological evaluation of water in the Rio Grande and Taquacetuba branches of the Billings complex (São Paulo, Brazil) and the management implications. Ambi-água 5 (3), 47-59.

Muncke, J., Eggen, R.I., 2006. Vitellogenin 1 mRNA as an early molecular biomarker for endocrine disruption in developing zebrafish (Danio rerio). Environ. Toxicol. Chem. 25, 2734-2741. https://doi.org/10.1897/05-683R.1.

Oliveira, T.A., 2012. Metais Presentes na Agua e em Tecidos de Peixes da Represa Billings: Uma Avaliação Temporal (Master Dissertation). Instituto de Pesquisa Energéticas e Nucleares, Universidade de São Paulo, São Paulo. https://doi.org/10.11606/D85. 2012.

Orn, S., Yamani, S., Norrgren, L., 2006. Comparison of vitellogenin induction, sex ratio, and gonad morphology between zebrafish and Japanese medaka after exposure to 17 alpha-ethinylestradiol and 17beta-trenbolone. Arch. Environ. Contam. Toxicol. 51, 237-243. https://doi.org/10.1007/s00244-005-0103-y.

Prado, S.P., Souza, C.C., Bazzoli, N., Rizzo, E., 2011. Reproductive disruption in lambari Astyanax fasciatus from a Southeastern Brazilian reservoir. Ecotox. Environ. Safe 74, 1879-1887. https://doi.org/10.1016/j.ecoenv.2011.07.017.

Quintero-Hunter, I., Grier, H., Muscato, M., 1991. Enhancement of histological detail using metanil yellow as counterstain in periodic acid Schiff'hematoxylin staining of glycol methacrylate tissue sections. Biotech. Histochem. 66, 169-172. https://doi. org/10.3109/10520299109109964.

Rocha, A.A., Pereira, D.N., Pádua, H.B., 1985. Produtos de pesca e contaminantes químicos na água da represa Billings, São Paulo (Brasil). Rev. Saúde Públ. 19, $401-410$.

Salierno, J.D., Kane, A.S., 2009. 17 $\alpha$-Ethinylestradiol alters reproductive behaviors, circulating hormones, and sexual morphology in male fathead minnows (Pimephales promelas). Environ. Toxicol. Chem. 28, 953-961. https://doi.org/10.1897/08-111.1.

Sanchez, W., Porcher, J.M., 2009. Fish biomarkers for environmental monitoring within the water frame work. Directive of the European Union. Trend Anal. Chem. 28, 150-158. https://doi.org/10.1016/j.marpolbul.2011.06.028.

Scholz, S., Kordes, C., Hamann, J., Gutzeit, H.O., 2004. Induction of vitellogenin in vivo and in vitro in the model teleost medaka (Oryzias latipes): comparison of gene expression and protein levels. Mar. Environ. Res. 57, 235-244. https://doi.org/10. 1016/S0141.

Schulz, U.H., Martins-Júnior, H., 2001. Astyanax fasciatus as bioindicator of water pollution of Rio dos Sinos, RS, Brazil. Braz. J. Biol. 61, 615-622.

Silva, J.P.A., Muelbert, A.E., Oliveira, E.C., Fávaro, L.F., 2010. Reproductive tactics used by the lambari Astyanax aff. fasciatus in three water supply reservoirs in the same geographic region of the upper Iguaçu River. Neotrop. Ichthyol. 8, 885-892. https:// 
doi.org/10.1590/S1679-62252010000400019.

Tan, B.L., Hawker, D.W., Müller, J.F., Leusch, F.D., Tremblay, L.A., Chapman, H.F., 2007. Comprehensive study of endocrine disrupting compounds using grab and passive sampling at selected waste water treatment plants in South East Queensland, Australia. Environ. Int. 33, 654-669. https://doi.org/10.1016/j.envint.2007.01.008.

Tetreault, G.R., Bennett, C.J., Shires, K., Knight, B., Servos, M.R., Mc Master, M.E., 2011. Intersex and reproductive impairment of wild fish exposed to multiple municipal waste water discharges. Aquat. Toxicol. 104, 278-290. https://doi.org/10.1016/j. aquatox.2011.05.008.

Urbatzka, R., Rocha, E., Reis, B., Cruzeiro, C., Monteiro, R.A.F., Rocha, M.J., 2012. Effects of ethinylestradiol and of an environmentally relevant mixture of xenoestrogens on steroidogenic gene expression and specific transcription factors in zebrafish. Environ. Pollut. 164, 28-35. https://doi.org/10.1016/j.envpol.2012.01.018.

USEPA, 2000. Supplementary guidance for conducting health risk assessment of Chemical Mixtures. US Environmental Protection Agency, Washington DC, pp. 209.

Vázquez, G.R., Meijide, F.J., Da Cuña, R.H., Lo Nostro, F.L., Piazza, Y.G., Babay, P.A. Trudeau, V.L., Maggese, M.C., Guerrero, G.A., 2009. Exposure to water borne 4- tert octylphenol induces vitellogenin synthesis and disrupt testis morphology in the South American fresh water fish Cichlasoma dimerus (Teleostei, Perciformes). Comp.
Biochem. Phys. C. 50, 298-306. https://doi.org/10.1016/j.cbpc.2009.05.012.

Vazzoler, A.E.A.M., 1981. Manual de métodos para estudos biológicos de populações de peixes: Reprodução e crescimento, first ed. CNPq, Brasília.

Vazzoler, A.E.A.M., 1996. Biologia da reprodução de peixes teleósteos: Teoria e Prática, first ed. Nupelia, Maringá. p. 196.

Vested, A., Giwercman, A., Bonde, J.P., Toft, G., 2014. Persistent organic pollutants and male reproductive health. Asian J. Androl. 16, 71-80. https://doi.org/10.1007/ s00244-015-0218-8.

Vetillard, A., Bailhache, T., 2006. Effects of 4-n-nonylphenol and tamoxifen on salmon receptor and vitellogenin gene expression in juvenile rainbow trout. Toxicol. Sci. 92, 523-544. https://doi.org/10.1093/toxsci/kfl015.

Vilella, F.S., Becker, F.G., Hartz, S.M., 2002. Diet of Astyanax species (Teleostei, Characidae) in an Atlantic Forest River in Southern Brazil. Braz. Arch. Biol. Technol. 42, 223-232.

Xu, H., Yang, J., Wang, Y., Jiang, Q., Chen, H., Song, H., 2008. Exposure to 17alphaethynylestradiol impairs reproductive functions of both male and female zebrafish (Danio rerio). Aquat. Toxicol. 88, 1-8. https://doi.org/10.1016/j.aquatox.2008. 01.020 . 